\title{
Effect of Microbial Consortia on Growth, Nodulation, Yield and Nutrient Uptake of Soybean in Vertisol of Central India
}

\author{
Bablu Yaduwanshi*, R.K.Sahu, N.G. Mitra, F. C. Amule and Shishram Jakhar \\ Department of soil science and Agricultural Chemistry, Jawaharlal Nehru Krishi Vishwa \\ Vidhyalaya, Jabalpur, Madhya Pradesh-482004, India \\ *Corresponding author
}

\section{A B S T R A C T}

Keywords

soybean,

Arthrobacter,

Psuedomonas,

PGPR, nodulation,

Vertisol, FUI

Article Info

Accepted:

24 August 2019

Available Online:

10 September 2019
A field experiment on "Effect of microbial consortia on growth, nodulation, yield and nutrient uptake of soybean" was carried out during Kharif 2018-19 under the Department of Soil Science \& Agricultural Chemistry.The experiment was laid out under $\mathrm{r}$ andomized block design (RBD) with 3 replications and 9 treatments comprising beneficial microorganisms of Actinomycetes, Arthrobacter and PGPR (P. fluorescens) in possible co mbinations applied as seed treatments and additionally P.fluorescens was applied as foliar application at 20,40 and 60 DAS of the crop growth stages. The crop was supplemented with recommended dose of fertilizers 20:80:20 ( N: $\left.\mathrm{P}_{2} \mathrm{O}_{5}: \mathrm{K}_{2} \mathrm{O} \mathrm{kg} \mathrm{ha}{ }^{-1}\right)$ at basal application. Besides these, two types of control plots were maintined as fertilized uninoculated control (FUI) and unfertilized uninoculated control (UFUI). Results revealed that the significant improvement were noticed in plant growth attributes of nodulation ( 57 and $43.5 \%$ ), over control (9.5 and 33.4 nodule plant ${ }^{-1}$ ) and its biomass, (71 and 43\%),over the control (0.38and 1.12 g plant $^{-1}$ ) plant height $47,38,32 \%$ over the control $(16.3,35$ and $45.4 \mathrm{~cm})$ and its biomass, (39, 57 and 65\%), over the control 1.22, 3.41and $6.07 \mathrm{~g} \mathrm{plant}^{-1}$ leaf chlorophyll content (32 and $31.0 \%$ ) over the control (2.65 and $2.92 \mathrm{mg} \mathrm{g}^{-1}$ leaf) all at 25 , 45 and 65 DAS, nutrient contents (N, P and K seed and stover respectively) 58 and $122 \%$, 65 and $101 \%, 70$ and $86 \%$ over the control $98.5,63.8,5.2,7.4,24.9$ and $44.4 \mathrm{~kg} \mathrm{ha}^{-1}$, yields 44 and $61 \%$ over the control 1636 and $3345 \mathrm{~kg} \mathrm{ha}^{-1}$ respectively (seed and stover) at harvest of the crop.

\section{Introduction}

Soybean is the most important oil seed crop in India which contains $35-40 \%$ protein, $19 \%$ oil, 35\% carbohydrate, 5\% minerals and several other components including vitamins (Liu, 1997). In Madhya Pradesh the area under soybean cultivation is 54.100 lakh ha. with $1,094 \mathrm{~kg}$ ha-1 yield and 59.170 lakh MT production (SOPA, 2018). Soybean rhizosphere harbors vast proportions soil microorganisms, whose activities largely determine the biological condition of the soil and influence the plant growth right from seed germination to maturity (Egamberdiyeva, 2005). Among nitrogen fixing microorganisms in soybean rhizosphere Arthrobacter is a typical diazotroph. 
The microbe is a rod shaped aerobic Grampositive becomes cocci at stationary growth phase that favours the crop with nutrient supplements including indeterminate way of $\mathrm{N}$ fixation and tolerance at moisture stress condition. Some species of Arthrobacter have been acknowledged for oxygen independent growth strategies under limited oxygen.

These species also under restriction of oxygen use nitrate as an electron. A number of evidence has been established that PGPR comprising Pseudomonas plays a major role in functioning of the biosphere. These bacteria stimulate the growth of plants through direct and indirect beneficial effects viz., enhancing diazotrophy, nutrient solubilization, sederophore formation for $\mathrm{Fe}$ availability, excretion of growth promoting enzymes (IAA, GA, ABA, cytokinin, etc.), vigorous growth via ACC-deaminase activity, plants systemic resistance (ASR and ISR(acquired and induced systemic resistance), and antioxidants (Bharadwaja et al., 2008 and Kumar et al., 2013) acceptor at the end of their respiratory chain, reducing it to ammonia via nitrite.

Actinomycetes are versatile group of microorganism habitually aerobic, performing important activities in soil like production of growth promoting substances, phosphorus solubilization, decomposition of organic matter, antibiotic production for suppression of soil borne plant pathogens etc. (Franco and Valencia, 2001).

Arthrobacter, actinomycetes and $P$. fluorescence individually are found beneficial but their co-inoculation in the form of a consortium acts as reinforced source to augment diazotrophy, nutrient solubilization, plant growth promoter and protectant against soil borne pathogens especially under moisture stress condition encountered by the crop.

\section{Materials and Methods}

The experiment was carried out during Kharif 2018 at the Research field Department of Soil Science and Agricultural Chemistry, JNKVV, Jabalpur. Under the project AINP on Soil Biodiversity \& Biofertilizers (ICAR), JNKVV, Jabalpur.

The recommended dose of fertilizer @ 20:80:20 kg ha ${ }^{-1}\left(\mathrm{~N}: \mathrm{P}_{2} \mathrm{O}_{5}: \mathrm{K}_{2} \mathrm{O}\right)$ for soybean crop was applied in the form of urea, single super phosphate (SSP) and murate of potash (MOP). SSP and MOP were supplemented as basal applications to each plot as per recommendation.

One $\mathrm{ml}$ of gum acacia sticker solution was poured on the seed of each polythene bag followed by one $\mathrm{ml}$ of liquid formulations of different isolates and its consortium. By holding the mouth of polythene bags seeds were enough shaken to get mixed with the sticker and inoculants formulation so that each seed receive proper coating.

\section{Nodulation}

Nodulation studies were done at 25 and 45 days of sowing by uprooting 3 plants plot $^{-1}$ very carefully taking sufficient care to avoid any losses or damage of nodules. After proper washing nodules of plants per plot were counted. After counting, the nodules were detached from the roots and were kept in small paper bags. Then the nodule fresh weight was taken. Nodules were oven dried in hot air oven at $60^{\circ} \mathrm{C}$ for (18-20 hrs) 3-4 days (till constant weight) to record their oven dried weight.

\section{Plant height and plant dry biomass}

Plant height and plant dry biomass was measured at 25, 45 and 65 DAS. Three plants from each plot were taken and their heights dry weight was measured. 


\section{Chlorophyll content}

Leaf chlorophyll ( $\mathrm{a}, \mathrm{b}$ and total) content was estimated by acetone extraction method in fresh plant leaves at 25 and 45 DAS.

\section{Digestion of plant samples}

The plants samples were subjected to wet digestion for estimation of various nutrients in grain and straw Mixture of $\mathrm{HNO}_{3}$ and $\mathrm{HClO}_{4}$ was added in 2.5:1 ratio (v/v) for estimation of major nutrients.

\section{Total nitrogen}

The nitrogen content of soybean plant was estimated on dry weight basis by microkjeldahl method as per procedure suggested by AOAC (1995).

\section{Total phosphorus and potassium}

The phosphorus contents in grain and straw of soybean were estimated on dry weight basis by vanado-molybdate yellow colour method as suggested by Bhargava and Raghupathi (1984). The potassium content in the digested material was directly estimated. Nutrients uptake by soybean was calculated in $\mathrm{kg} \mathrm{ha}^{-1}$ in relation to dry with a flame photometer using the procedure of Bhargava and Raghupathi (1984).matter production by using the following formula.

Nutrient uptake $\left(\mathrm{kg} \mathrm{ha}^{-1}\right)$ content $(\%)$ x yield $\left(\mathrm{kg} \mathrm{ha}^{-1}\right)$

\section{0}

\section{Results and Discussion}

\section{Nodulation studies}

The data on Nodulation of soybean is given in Table 1. the maximum Nodulation at 25 DAS was increased with the microbial consortium of PGPR + Arthrobacter+ Actinomycetes recorded the significantly higher nodules number (14.3 No. plant ${ }^{-1}$ ) by $57 \%$ response, followed by PGPR+ Arthro, PGPR+Actino, Arthro+Actino, and PGPR with number of nodules 13.7, 13.2, 12.3 and 11.7 along with response of 44.2, 42.129 .4 and $23.2 \%$, respectively over FUI (9.5 nodules plant $\left.{ }^{-1}\right)$. Similarly, the maximum number of nodules of 48 No. plant $^{-1}$ at 45 DAS was recorded by treatment combination of PGPR+ Arthro+Actino with $43.7 \%$ increment, followed by PGPR+Arthro and PGPR+Actino with nodule 41.3 and 40.8 No. plant $^{-1}$ by 23.65 and $22.15 \%$ response, respectively over FUI (33.4 nodules No. plant ${ }^{-1}$ ). Jakhar et al., (2018) Treatment P80+LRh (80 kg $\mathrm{P}_{2} \mathrm{O}_{5}+$ liquid inoculum of Rhizobium) for enhanced the nodulation attributes, over the control at 45 DAS. The treatment P80+LRh gave maximum nodules number $(81.1 \%)$, weight $(89.1 \%$ fresh and $78.5 \%$ dry) and $\mathrm{N}$ content $(64.4 \%)$ over control (6.9 number/plant, $103 \mathrm{mg} /$ plant, 65 $\mathrm{mg} /$ plant and $2.03 \%$ ), respectively.

The data related to nodule dry weight at 25 and 45 DAS of soybean were recorded and revealed that the consortium of PGPR+ Arthro+Actino gave the significantly higher nodule dry wt. $0.65 \mathrm{~g}$ with an increment $71 \%$ over FUI (0.38 g), followed by PGPR+Arthro, PGPR+Actino, Arthro+Actino and PGPR with nodule dry wt. $0.54,0.53,0.51$ and $0.49 \mathrm{~g}$ along with percent response $71,42,39,34$ and $29 \%$, respectively over FUI $(0.38$ g nodules plant $\left.^{-1}\right)$. Similarly, nodule dry weight plant $^{-1}$ of soybean at 45 DAS recorded maximum with consortium PGPR+Arthro+Actino as significantly highest ( $1.60 \mathrm{~g}$ ) compared to FUI $(1.12 \mathrm{~g})$ by $43 \%$ response followed by PGPR+Arthro, PGPR+Actino and Arthro+ Actino with nodule dry weight of $1.38,1.36,1.33$ and $1.30 \mathrm{~g}$ plant $^{-1}$ these treatment responded $23,21,19$ and $16 \%$ over FUI. The actinomycetes consortium (consortium of different strains of actonomycetes) and Rhizobium consortia along with PGPR consortia was found most 
effective among microbial inoculants, in respect of symbiotic parameters including nodule number, nodule dry weight Gopalakrishnan et al., (2015). The consortia of bradyrhizobia (Bradyrhizobium japonicum) and phosphate solubilizing bacteria (Pseudomonas sp.) as liquid inoculants on soybean enhanced the nodule number, fresh weight and dry weight of nodules Amule et al.,(2018).

\section{Plant height and biomass}

The data on Plant height and its biomass of soybean is given in Table 2 and 3.

plant height of $23.9 \mathrm{~cm}$ at 25 DAS was responded maximum with the treatment combination of PGPR + Arthrobacter+ Actinomycetes and responded by $46.62 \%$ over the FUI $(16.3 \mathrm{~cm})$ followed by PGPR+Arthro, PGPR+Actino, Arthro +Actino with plant height of $22.4 \mathrm{~cm}, 21.9 \mathrm{~cm}$ and $21.5 \mathrm{~cm}$ along with 37.42, 34.29 and $31.90 \%$ response, respectively.

Similarly at 45 DAS the plant height (48.3 $\mathrm{cm}$ ) was significantly influenced by the treatment combination of PGPR+ Arthro+Actino with an increment $38 \%$, over FUI $(35 \mathrm{~cm})$ followed by $\mathrm{PGPR}+$ Arthro, PGPR+ Actino, Arthro+Actino, with plant height of $45 \mathrm{~cm}, 44.3 \mathrm{~cm}, 43 \mathrm{~cm}$ and $42.3 \mathrm{~cm}$ and response increase by $28.57,26.57,22.85$ and $20.85 \%$, respectively.

The plant height $(59.8 \mathrm{~cm})$ of soybean at 65 DAS exhibited of the significantly higher plant height $(59.8 \mathrm{~cm})$ was found associated with PGPR+Arthro+Actino with an increment $31.7 \%$ over FUI $(45.4 \mathrm{~cm})$. This was followed by PGPR+Arthro, PGPR+ Actino, Arthro+Actino with plant heights of $57.5 \mathrm{~cm}$, $57.1 \mathrm{~cm}$, and $55.5 \mathrm{~cm}$ along with response increase by 26.6, 25.7, and $22.2 \%$, respectively. It is well documented that soil microorganisms exert a beneficial effect on plant growth and development. In fact, many microorganisms are being commercialized to be used in agriculture Bashan et al., (2014).

The dry biomass $1.70 \mathrm{~g} \mathrm{plant}^{-1}$ of soybean plant at 25 DAS was gained maximum by the consortium PGPR+Arthro+Actino with $39 \%$ response over the control FUI (1.22 $\left.\mathrm{g} \mathrm{plant}^{-1}\right)$ followed by $\mathrm{PGPR}+$ Arthro and PGPR+Actino with plant dry biomass of 1.63 and 1.56 along with 34 and $28 \%$ response, respectively.

Similarly the dry biomass at 45 DAS the treatment combination of PGPR + Arthro+Actino increased the plant dry biomass by $5.14 \mathrm{~g} \mathrm{plant}^{-1}$ with $51 \%$ response over FUI (3.41 $\mathrm{g} \mathrm{plant}^{-1}$ ) followed by the consortium PGPR + Arthro with plant biomass of $4.52 \mathrm{~g} \mathrm{plant}^{-1}$ by $33 \%$ increment over FUI (3.41 $\left.\mathrm{g} \mathrm{plant}^{-1}\right)$.

The highest plant biomass at 65 DAS of $10 \mathrm{~g}$ plant $^{-1}$ recorded by application of PGPR+Arthro+Actino with an increment of $65 \%$ over the control FUI (6.07 $\mathrm{g} \mathrm{plant}^{-1}$ ) followed by PGPR+Arthro and PGPR+Actino with plant dry biomass of 8.86 and $8.48 \mathrm{~g}$ plant $^{-1}$ by 43 and $40 \%$ response, respectively. Jha and Saraf (2012) also reported that the root and shoot biomass were maximized with microbial consortia compared to both control and individual trials of microorganisms.

Linu (2009) also confirmed the findings that the seed inoculation in cowpea by phosphate solublizers improved nodulation, root and shoot biomass, stover and seed yield and phosphorous and nitrogen uptake by crop. Coinoculation of $G$. fasciculatum, P. fluorescens and $A$. chrococcum enhanced shoot and root biomass of tomato (Kavatagi et al., 2014).

\section{Chlorophyll content}

The chlorophyll content in the leaf were presented in Table 4. The maximum total 
chlorophyll content $\left(3.51 \mathrm{mg} \mathrm{g}^{-1}\right.$ of leaf) was obtained by the application of PGPR + Arthro +Actino consortium which gives $32 \%$ response over FUI (2.65 $\mathrm{mg} \mathrm{g}^{-1}$ of leaf), followed by $\mathrm{PGPR}+$ Arthro and $\mathrm{PGPR}+$ Actino with chlorophyll content of 3.38 and $3.23 \mathrm{mg}$ $\mathrm{g}^{-1}$ of leaf by 28 and $23 \%$ response, respectively. Similarly, the data on chlorophyll content at 45 DAS all the treatment combinations, the consortium of PGPR+Arthro+Actino performed significantly better for the leaf chlorophyll content of 3.85 $\mathrm{mg} \mathrm{g}^{-1}$ with $31 \%$ increment over the control of FUI (2.92 $\mathrm{mg} \mathrm{g}^{-1}$ ), followed by PGPR+Actino and Arthro+Actino with total chlorophyll content of $3.55,3.50$ and $3.45 \mathrm{mg} \mathrm{g}^{-1}$ of leaf by 22,20 and $18 \%$ response, respectively. The PGPR had profound effect on the pigment contents on all the sampling days $(25,50,75$ and 100 DAS).

Similar finding suggested that the highest chlorophyll ' $a$ ', chlorophyll ' $b$ ' and total chlorophyll $\left(0.805,0.740\right.$ and $1.545 \mathrm{mg} \mathrm{g}^{-1}$ of leaf) were recorded in 75 days old crop plants grown with Rhizobium+ Pseudomonas+ Bacillus and declined in 100 DAS (Mathivanan et al., 2017).

The PGPR (Azospirillum, Azotobacter and Pseudomonas) application increased Chlorophyll 'a', Chlorophyll ' $b$ ' and total chlorophyll. Al-Erwy et al., (2016) reported that the A. globiformis enhanced plant biomass, uptake of iron and phosphate, protein and chlorophyll contents. Iron plays an important role in chlorophyll biosynthesis pathway.

Nitrogen, phosphorus and potassium uptake by crop

The nitrogen, phosphorus and potassium uptake by the soybean seed and stover were presented in Table 5. The consortium of isolates $\mathrm{PGPR}+$ Arthro+Actino was recorded maximum nitrogen uptake of $155.7 \mathrm{~kg} \mathrm{~N}^{-1}$ by seed and $142.0 \mathrm{~kg} \mathrm{~N} \mathrm{ha}^{-1}$ by stover of soybean over FUI of seed $\left(98.5 \mathrm{~kg} \mathrm{~N} \mathrm{ha}^{-1}\right)$ and stover $\left(63.8 \mathrm{~kg} \mathrm{~N} \mathrm{ha}^{-1}\right)$.

It was interesting to note that the percent increment were computed 58 and $122 \%$, by seed and straw, respectively next to PGPR+Arthro, PGPR+Actino, Arthro+ Actino and PGPR with $\mathrm{N}$ uptake by seed of 133.2, $130.3,123.7$ and $121.1 \mathrm{~kg} \mathrm{~N} \mathrm{ha}^{-1}$ as well as $\mathrm{N}$ uptake by stover of 107, 106, 95.9 and $94.0 \mathrm{~kg}$ $\mathrm{N} \mathrm{ha}^{-1}$.

Similarly, studied that the effectiveness of $B$. japonicum strains on soybean gave significant positive effect on $\mathrm{N}$ content in shoot, $\mathrm{N}$ uptake by shoot and seed with inoculation by $B$. japonисит or the mixed culture of strains $B$. japonucum. Solaiman and Hossain (2006). The consortium of PGPR+Arthro+Actino were obtained significantly maximum $P$ uptake of $8.6 \mathrm{~kg} \mathrm{P} \mathrm{ha}^{-1}$ by seed and $14.9 \mathrm{~kg} \mathrm{P}$ $\mathrm{ha}^{-1}$ by stover of soybean as compare to FUI of seed (5.2 kg P ha $\left.{ }^{-1}\right)$ and stover( $\left.7.4 \mathrm{kgP} \mathrm{ha}^{-1}\right)$.

The percent responses were calculated 65 and $101 \%$, P uptake by seed and stover, respectively followed by $\mathrm{PGPR}+$ Arthro, PGPR+Actino, Arthro+Actino and PGPR with $\mathrm{P}$ uptake by seed of 7.1, 7.0, 6.6 and $6.4 \mathrm{~kg} \mathrm{P}$ $\mathrm{ha}^{-1}$ as well as $\mathrm{P}$ uptake by stover of 11.7 , $10.7,10.5$ and $10.5 \mathrm{~kg} \mathrm{P} \mathrm{ha}^{-1}$ due to the stimulatory effects of bacterial species such as Pseudomonas, Bacillus and Arthrobacter were observed on growth, yield, nitrogen and phosphorous uptake of cotton ( $G$. hirsutum) by Egamberdiyeva et al.,(2005). 
Table.1 Effect of microbial consortia on nodulation of soybean at different growth stages

\begin{tabular}{|c|c|c|c|c|c|c|c|c|}
\hline \multirow[t]{2}{*}{ Treatment } & \multicolumn{4}{|c|}{$\left(\right.$ Nodules Plant $\left.^{-1}\right)$} & \multicolumn{4}{|c|}{ Dry weight ( g plant $^{-1}$ ) } \\
\hline & $\begin{array}{l}25 \\
\text { DAS }\end{array}$ & sem & $\begin{array}{l}45 \\
\text { DAS }\end{array}$ & sem & $\begin{array}{l}25 \\
\text { DAS }\end{array}$ & sem & $\begin{array}{l}45 \\
\text { DAS }\end{array}$ & sem \\
\hline F+Actino & 10.7 & 1.15 & 37.0 & 5.85 & 0.43 & 0.21 & 1.23 & 0.37 \\
\hline F+Arthro & 10.1 & 2.25 & 36.8 & 5.23 & 0.47 & 0.13 & 1.25 & 0.17 \\
\hline F+PGPR & 11.7 & 1.21 & 38.9 & $\begin{array}{l}12.6 \\
6\end{array}$ & 0.49 & 0.17 & 1.30 & 0.42 \\
\hline F+Arthro+Actino & 12.3 & 1.76 & 39.9 & 8.00 & 0.51 & 0.08 & 1.33 & 0.27 \\
\hline F+PGPR+Actino & 13.2 & 2.98 & 40.8 & $\begin{array}{l}11.3 \\
5\end{array}$ & 0.53 & 0.05 & 1.36 & 0.38 \\
\hline F+PGPR+Arthro & 13.7 & 1.41 & 41.3 & $\begin{array}{l}11.0 \\
2\end{array}$ & 0.54 & 0.03 & 1.38 & 0.14 \\
\hline $\begin{array}{l}\text { F+PGPR+Arthro+Acti } \\
\text { no }\end{array}$ & 14.3 & 1.15 & 48.0 & 5.13 & 0.65 & 0.08 & 1.60 & 0.17 \\
\hline FUI & 9.5 & 1.5 & 33.4 & 7.79 & 0.38 & 0.07 & 1.12 & 0.53 \\
\hline UFUI & 9.1 & 1.21 & 31.6 & 6.93 & 0.32 & 0.18 & 1.05 & 0.23 \\
\hline Mean & 11.6 & & 38.6 & & 0.48 & & 1.29 & \\
\hline $\mathrm{SE}_{\mathrm{m}} \pm$ & 0.62 & & 2.52 & & 0.04 & & 0.09 & \\
\hline $\operatorname{LSD}(p=0.05)$ & 1.87 & & 7.57 & & 0.12 & & 0.26 & \\
\hline
\end{tabular}

Table.2 Effect of microbial consortia on plant height and dry biomass of soybean at different growth stages

\begin{tabular}{|l|l|l|l|l|l|l|}
\hline \multirow{2}{*}{ Treatment } & \multicolumn{3}{l}{ Plant height (cm) } & \multicolumn{3}{l|}{ Plant biomass(g plant } \\
\cline { 2 - 7 } & $\begin{array}{l}25 \\
\text { DAS }\end{array}$ & sem & $\begin{array}{l}45 \\
\text { DAS }\end{array}$ & sem & 65 DAS & sem \\
\hline F+Actino & 17.2 & 4.50 & 40.1 & 7.19 & 46.8 & 13.91 \\
\hline F+Arthro & 19.2 & 3.04 & 41.0 & 10.63 & 47.4 & 7.04 \\
\hline F+PGPR & 19.9 & 6.51 & 42.3 & 4.35 & 48.7 & 17.67 \\
\hline F+Arthro+Actino & 21.5 & 3.77 & 43.0 & 13.91 & 55.5 & 6.49 \\
\hline F+PGPR+Actino & 21.9 & 1.86 & 44.3 & 7.57 & 57.1 & 6.33 \\
\hline F+PGPR+Arthro & 22.4 & 5.94 & 45.0 & 6.28 & 57.5 & 7.15 \\
\hline $\begin{array}{l}\text { F+PGPR+Arthro+Acti } \\
\text { no }\end{array}$ & 23.9 & 4.99 & 48.3 & 5.72 & 59.8 & 5.87 \\
\hline FUI & & & & & & \\
\hline UFUI & 16.3 & 2.78 & 35.0 & 4.13 & 45.4 & 9.68 \\
\hline Mean & 15.5 & 4.02 & 32.0 & 4.33 & 44.8 & 5.10 \\
\hline SE \pm & 19.5 & & 36.8 & & 51.1 & \\
\hline LSD $(\mathbf{p}=\mathbf{0 . 0 5 )}$ & 1.22 & & 2.05 & & 3.25 & \\
\hline & 3.67 & & 6.15 & & 9.76 & \\
\hline
\end{tabular}


Table.3 Effect of microbial consortia on plant dry biomass of soybean at different growth stages

\begin{tabular}{|l|l|l|l|l|l|l|}
\hline \multirow{2}{*}{ Treatment } & \multicolumn{5}{|c|}{ Plant biomass(g plant } \\
\cline { 2 - 7 } & 25 DAS & sem & $\begin{array}{l}\text { 45DA } \\
\text { S }\end{array}$ & sem & 65 DAS & sem \\
\hline F+Actino & 1.31 & 1.3 & 3.51 & 3.10 & 6.40 & 1.33 \\
\hline F+Arthro & 1.33 & 0.16 & 3.63 & 1.44 & 6.55 & 1.08 \\
\hline F+PGPR & 1.40 & 1.35 & 3.70 & 0.71 & 6.91 & 1.07 \\
\hline F+Arthro+Actino & 1.45 & 0.57 & 3.81 & 3.80 & 7.30 & 1.80 \\
\hline F+PGPR+Actino & 1.56 & 0.87 & 3.87 & 0.96 & 8.48 & 1.26 \\
\hline F+PGPR+Arthro & 1.63 & 1.76 & 4.52 & 1.23 & 8.86 & 1.47 \\
\hline $\begin{array}{l}\text { F+PGPR+Arthro+Acti } \\
\text { no }\end{array}$ & 1.70 & 1.60 & 5.14 & 2.54 & 10.00 & 1.58 \\
\hline FUI & 1.22 & 1.13 & 3.41 & 0.87 & 6.07 & 0.95 \\
\hline UFUI & 1.17 & 1.41 & 3.37 & 2.36 & 5.63 & 0.98 \\
\hline Mean & 1.42 & & 3.88 & & 7.36 & \\
\hline SEm \pm & 0.09 & & 0.33 & & 0.455 & \\
\hline LSD (p=0.05) & 0.27 & & 0.98 & & 1.35 & \\
\hline
\end{tabular}

Table.4 Effect of microbial consortia on chlorophyll content of soybean at different growth stages

\begin{tabular}{|l|l|l|l|l|}
\hline \multirow{2}{*}{ Treatment } & \multicolumn{4}{|l|}{ Total chlorophyll content $\left(\mathbf{m g ~ g}^{-1}\right.$ leaf tissue) } \\
\hline F+Actino & 25 DAS & sem & 45 DAS & sem \\
\hline F+Arthro & 2.72 & \pm 0.80 & 3.06 & \pm 1.39 \\
\hline F+PGPR & 2.89 & \pm 0.63 & 3.11 & \pm 1.09 \\
\hline F+Arthro+Actino & 3.06 & \pm 0.81 & 3.31 & \pm 1.40 \\
\hline F+PGPR +Actino & 3.18 & \pm 1.32 & 3.45 & \pm 2.29 \\
\hline F+PGPR+Arthro & 3.23 & \pm 0.66 & 3.50 & \pm 1.14 \\
\hline F+PGPR+Arthro+Actino & 3.38 & \pm 0.66 & 3.55 & \pm 1.14 \\
\hline FUI & 3.51 & \pm 0.35 & 3.85 & \pm 0.61 \\
\hline UFUI & 2.65 & \pm 1.13 & 2.92 & \pm 1.97 \\
\hline Mean $_{\text {SE }} \pm$ & 2.63 & \pm 0.78 & 2.72 & \pm 1.35 \\
\hline LSD $(\mathbf{p}=\mathbf{0 . 0 5 )}$ & 3.03 & & 3.27 & \\
\hline
\end{tabular}


Table.5 Effect of microbial consortia on NPK uptake $\left(\mathrm{kg} \mathrm{ha}^{-1}\right)$ by seed and stover.

\begin{tabular}{|l|l|l|l|l|l|l|}
\hline \multirow{2}{*}{ Treatment } & \multicolumn{2}{|l|}{ N uptake } & \multicolumn{2}{l|}{ P uptake } & \multicolumn{2}{l|}{ K uptake } \\
\cline { 2 - 7 } & Seed & Stover & Seed & Stover & Seed & Stover \\
\hline F+Actino & 107.0 & 79.6 & 5.6 & 8.8 & 27.1 & 50.9 \\
\hline F+Arthro & 112.4 & 81.8 & 5.8 & 9.0 & 28.9 & 54.1 \\
\hline F+PGPR & 121.1 & 94.0 & 6.4 & 10.5 & 30.9 & 59.8 \\
\hline F+Arthro+Actino & 123.7 & 95.9 & 6.6 & 10.5 & 33.2 & 63.6 \\
\hline F+PGPR +Actino & 130.3 & 106.3 & 7.0 & 10.7 & 35.0 & 64.6 \\
\hline F+PGPR+Arthro & 133.2 & 107.0 & 7.1 & 11.7 & 35.2 & 68.9 \\
\hline F+PGPR+Arthro+Actino & 155.7 & 142.0 & 8.6 & 14.9 & 42.3 & 82.3 \\
\hline FUI & 98.5 & 63.8 & 5.2 & 7.4 & 24.9 & 44.4 \\
\hline UFUI & 86.0 & 45.9 & 4.5 & 6.4 & 22.0 & 39.2 \\
\hline Mean & 118.6 & 90.6 & 6.3 & 9.9 & 31.1 & 59.1 \\
\hline SE $\mathbf{m} \pm$ & 7.47 & 6.30 & 0.35 & 0.79 & 1.60 & 5.40 \\
\hline LSD $(\mathbf{p = 0 . 0 5 )}$ & 22.4 & 18.9 & 1.03 & 2.38 & 4.79 & 16.7 \\
\hline
\end{tabular}

Table.6 Effect of microbial consortia on seed and stover yields of soybean.

\begin{tabular}{|l|l|l|l|l|}
\hline \multirow{2}{*}{ Treatment } & \multicolumn{4}{|l|}{ Yield $\left(\mathbf{k g ~ h a}^{-\mathbf{1}}\right)$} \\
\cline { 2 - 5 } & Seed & sem & Stover & sem \\
\hline F+Actino & 1781 & \pm 280 & 3679 & \pm 779 \\
\hline F+Arthro & 1839 & \pm 322 & 3912 & \pm 351 \\
\hline F+PGPR & 1947 & \pm 456 & 4272 & \pm 833 \\
\hline F+Arthro+Actino & 1978 & \pm 384 & 4253 & \pm 1056 \\
\hline F+PGPR +Actino & 2037 & \pm 388 & 4162 & \pm 688 \\
\hline F+PGPR+Arthro & 2102 & \pm 390 & 4369 & \pm 1369 \\
\hline F+PGPR+Arthro+Actino & 2350 & \pm 160 & 5381 & \pm 1604 \\
\hline FUI & 1636 & \pm 163 & 3345 & \pm 685 \\
\hline UFUI & 1545 & \pm 315 & 3064 & \pm 1260 \\
\hline Mean & 1913 & & 4547 & \\
\hline SE $\mathbf{\pm}$ & 97.9 & & 315.7 & \\
\hline LSD $(\mathbf{p}=\mathbf{0 . 0 5 )}$ & 293.7 & & 946.6 & \\
\hline
\end{tabular}

The responses of the consortium of PGPR+Arthro+Actino were calculated 70 and $86 \% \mathrm{~K}$ uptake by seed and stover over FUI, respectively followed by PGPR + Arthro, PGPR+ Actino, Arthro+Actino and PGPR with $\mathrm{K}$ uptake by seed of 35.2, 35.0, 33.2 and $30.9 \mathrm{~kg} \mathrm{~K} \mathrm{ha}^{-1}$ as well as $\mathrm{K}$ uptake by stover of $68.9,64.6,63.6$ and $59.8 \mathrm{~kg} \mathrm{~K} \mathrm{ha}^{-1}$ might be attributed due to the potential $\mathrm{K}$ improvement and $\mathrm{P}$ nutrition by application of PGPR as biofertilizers for sustainable solution to improve plant nutrient status and production (Vessey, 2003). Higher K uptake may be attributable to the mobilization of nutrients from the soil because of the secretion of organic acids mediated by soil 
microorganisms (Basak and Biswas., 2010)

\section{Seed and stover yield of soybean}

The data on grain yield and biomass production of soybean is given in Table 6 . The grain yield of soybean differed significantly among all the treatments. The consortium of PGPR+ Arthro+Actino gave the significantly maximum grain yield of $2350 \mathrm{~kg} \mathrm{ha}^{-1}$ that was responded $44 \%$ over FUI (1636 $\mathrm{kg} \mathrm{ha}^{-1}$ ) followed by PGPR+Arthro, PGPR+ Actino, Arthro+Actino and PGPR with grain yield of 2102, 2037, 1978 and $1947 \mathrm{~kg} \mathrm{ha}^{-1}$ along with the increment of $28,25,21$ and $19 \%$, respectively. This increment in yields of soybean with the treatments of inoculation fertilization might be attributed to better nodulation, $\mathrm{N}_{2}$ fixation and crop growth as against uninoculated control (Brahmaprakash et al., 2004 and Gupta, 2005). Moreover, the co-inoculation of Bradyrhizobium and Pseudomonas strains along with $\mathrm{P}_{2} \mathrm{O}_{5}$ enhanced the grain yield of soybean by $38 \%$ in pot experiments and $12 \%$ in the field experiment, over $\mathrm{P}_{2} \mathrm{O}_{5}$ alone (Afzal et al., 2010).

Similarly, the highest stover yield of soybean $\left(5381 \mathrm{~kg} \mathrm{ha}^{-1}\right)$ was recorded with the treatment combination of PGPR+Arthro+Actino by $61 \%$ response over the control FUI $\left(3345 \mathrm{~kg} \mathrm{ha}^{-}\right.$ $\left.{ }^{1}\right)$ followed by the treatment combination of $P$ GPR+Arthro with stover yield of $4369 \mathrm{~kg} \mathrm{ha}$ ${ }^{1}$ by $31 \%$ which has been supported by the findings of Amule et al., (2018) the inoculation of microbial consortium (actinomycetes, Rhizobium and PGPR) supplemented with recommended dose of fertilizer gave the significant improvement in seed and stover yield of soybean over fertilize $\mathrm{d}$ uninoculated.

\section{References}

Afzal A, Bano, A and Fatima M. 2010. Higher soybean yield by inoculation with $\mathrm{N}$ fixing and P-solubilizing bacteria. Agronmybacterial resistance Sustainable Development. 30: 487495.

AL-Erwy AS, Bafeel SOand Al-Toukhy A. 2016. Effect of Chemical Organic and Bio Fertilizers on Germination Growth and yield of Wheat (Triticum aestivum. L) Plants Irrigated With Sea Water. seeds 10, 100.

Amule FC, Sirothiya P,Rawat AK and Mishra US. 2018. Efficacy of actinomycetes Rhizobium and plant growth promoting rhizobacteria consortium inoculants on symbiotic traits nodule leghemoglobin and yield of soybean. International Journal of Chemical Studies 6(1): 593596.

Amule FC, Sirothiya P, Rawat AK and Mishra US. 2018. Effect of actinobacterial Rhizobium and plant growth promoting rhizobacteria consortium inoculation on rhizosphere soil properties in soybean in Jabalpur district of Madhya Pradesh. International Journal of Chemical Studies 6(1):583-586.

Basak BB and Biswas DR. 2010. Coinoculation of potassium solubilizing and nitrogen fixing bacteria on solubilization of waste mica and their effect on growth promotion and nutrient acquisition by a forage crop. Biology and Fertility of Soils 46(6):641-648.

Bashan Yde, Bashan LE, Prabhu SR and Hernandez JP. 2014. Advances in plant growth-promoting bacterial inoculant technology: formulations and practical perspectives (1998-2013). Plant and Soil 378 (1-2):1-33.

Bhargava, BS and Raghupathi HB. 1984. Analysis of plant materials for macro and micronutrients. pp. 49-82.

Brahmaprakash GP,Girisha HC, Navi Vithal and Hedge SV. 2004. Biological 
nitrogen fixation in pulse crops. Pulses in New Perspective (Masood Ali B.B Singh Shiv Kumar and Vishwa Dhar eds.) Indian Society of Pulses Research and Development IIPR Kanpur India pp. 271 - 86.

Bharadwaj DP, Lundquist PO andAlström S. 2008. Arbuscular mycorrhizal fungal spore-associated bacteria affect mycorrhizal colonization, plant growth and potato pathogens. Soil Biology and Biochemistry. 40(10):2494-2501.

Egamberdiyeva

D.

2005.

Plant-growth-promoting rhizobacteria isolated from a Calcisol in a semi-arid region of Uzbekistan, biochemical characterization and effectiveness. Journal of Plant Nutrition and Soil Science 168(1):9499.

Franco M and Valencia H. 2001. Evaluation of actinomycetes as growth inhibitors of Fusarium oxysporumf. sp.dianthi in carnations (Dianthus caryophyllus var rosana) ASCOLFI-Informa Cali Colombia 27(6):40-43.

Gupta SC. 2005. Evaluation of liquid and carrier based Rhizobium inoculants in chickpea. Indian Journal Pulses Research 18(1):40-42.

Gopalakrishnan,SV., Srinivas G., Alekhya B and Prakash. 2015. Effect of plant growth-

promoting Streptomyces sp. On growth promotion and grain yield in chickpea springer.com/article/ 101007/s13205015-0283-8.

Jakhar SR, Kumar V, Mitra NG, Singh O. 2018. Effect of Soybean (Glycine max) Seed Inoculation with Liquid and Carrier Based Rhizobium cultures and Phosphorus Levels on Productivity and Physico-Chemical Properties of Soil International Journal of Current Microbiology and Applied Sciences7(6):1807-1814.
Jha CK and Saraf M. 2012. Evaluation of Multispecies Plant-Growth-Promoting consortia for the growth promotion of Jatropha curcas (L.). Journal of plant growth regulation 31(4):588-598.

Kavatagi PK. 2014. Arbuscular mycorrhizal fungi studies on some varieties of solanum lycopersicum $\mathrm{L}$.

Kumar R., Shanthy S., Kalaiarasi SA and Sumaya S. 2013. Halophilic phosphobacteria for raising vigorous growth improvement in Rice (Oryzasativa). African Journal of Agricultural Research 8(18): 18721876.

Linu MS., Stephen J and Jisha MS. 2009. Phosphate solubilizing Gluconacetobacter sp., Burkholderia sp. and their potential interaction with cowpea (Vigna unguiculata (L.). International Journal Agriculture Research 4(2): 79-87.

Liu K. 1997. Chemistry and nutritional value of soybean components In Soybeans (pp 25-113) Springer Boston.

Mathivanan S., Chidambaram AA., Robert GA and Kalaikandhan R. 2017. Impact of PGPR inoculation on photosynthetic pigment and protein contents in Arachis hypogaea (L.). Journal of Scientific Agriculture (1):29-36.

Solaiman ARM and Hossain D. 2006. Effectiveness of Bradyrhizobium japonucum strains on soybean at field condition Bulletin of the Institute of Tropical Agriculture Kyushu University 29(1):11-20.

SOPA. 2018.The Soybean Processors Association of India e-mail: sopa@sopaorg.

Vessey JK. 2003. Plant growth promoting rhiz obacteria as biofertilizers. Plant and soil 255(2):571-586. 


\section{How to cite this article:}

Bablu Yaduwanshi, R.K.Sahu, N.G. Mitra, F. C. Amule and Shishram Jakhar. 2019. Effect of Microbial Consortia on Growth, Nodulation, Yield and Nutrient Uptake of Soybean in Vertisol of Central India. Int.J.Curr.Microbiol.App.Sci. 8(09): 2649-2659. doi: https://doi.org/10.20546/ijcmas.2019.809.306 